\title{
ПАТЕНТНІ ПОШУКИ ЯК ІНСТРУМЕНТ ЗАБЕЗПЕЧЕННЯ НАУКОВО-ТЕХНІЧНОГО ПРОГРЕСУ ТА ЕКОНОМІЧНОГО ЗРОСТАННЯ
}

\section{PATENT SEARCHES AS AN INSTRUMENT TO ENSURE SCIENTIFIC, TECHNICAL AND ECONOMIC PROGRESS}

\author{
Олійничук Олександра Іванівна \\ кандидат економічних наук, доцент, \\ Західноукраїнський національний університет \\ ORCID: https://orcid.org/0000-0001-9359-7560
}

Oliynychuk Oleksandra

West Ukrainian National University

\begin{abstract}
Стаття присвячена актуальним питанням проведення патентних пошуків. Розглянуто структуру та переваги патентної інформації. Узагальнено вітчизняні бази даних у сфері інтелектуальної власності, а також здійснено огляд баз даних інших країн та міжнародних організацій. Зроблено висновок, що світовою спільнотою напрацьовано ефективний механізм виконання патентних досліджень, що забезпечує ґрунтовність, всебічність, релевантність отриманих даних. Окреслено цілі патентних досліджень та типи патентних пошуків за різними базами даних, а саме на предмет актуальності винаходу та шляхів вирішення технічної проблеми; новизни винаходу; дійсності патенту; іменний патентний пошук; пошук на предмет непорушення прав третіх осіб. Обґрунтовано висновок про роль патентної інформації для забезпечення подальшого науково-технічного та економічного розвитку.
\end{abstract}

Ключові слова: патентна інформація, патентні пошуки, бази даних, типи патентних пошуків, науковотехнічний прогрес, економічний розвиток.

Статья посвящена актуальным вопросам проведения патентных поисков. Рассмотрена структура и преимущества патентной информации. Обобщено отечественные базы данных в сфере интеллектуальной собственности, а также осуществлен обзор баз данных других стран и международных организаций. Сделан вывод, что мировым сообществом наработан эффрективный механизм выполнения патентных исследований, который обеспечивает основательность, всесторонность, релевантность полученных данных. Определены цели патентных исследований и типы патентных поисков по разным базам данных, а именно на предмет актуальности изобретения и путей решения технической проблемы; новизны изобретения; действительности патента; именной патентный поиск; поиск на предмет нарушения прав третьих лиц. Обоснован вывод о роли патентной информации для обеспечения дальнейшего научно-технического и экономического развития.

Ключевые слова: патентная информация, патентные поиски, базы данных, типы патентных поисков, научно-технический прогресс, экономическое развитие.

The article is devoted to topical issues of patent searches. The structure and advantages of patent information are considered. Domestic databases in the field of intellectual property are generalized and it is concluded that in Ukraine a powerful network of databases has been formed, which contains a significant array of accumulated patent information. However, intellectual property is a concept not of regional but of global significance, and therefore databases of other countries and international organizations are especially relevant and in demand for patent research. A review of databases of other countries and international organizations, namely the World Intellectual Property Organization, the European Patent Office, the US Patent Office, Australia, Japan, the Russian Federation, as well as Google's patent search service are made. It is concluded that the world community has developed an effective mechanism for patent research, which ensures the thoroughness, comprehensiveness, relevance of the data in terms of countries, industries, individual patent offices, applicants, inventors. The purposes of patent researches are generalized to which the estimation of possibility of patenting of the developed technical decision is carried; assessment of the risks of violation of the rights of third parties and the likelihood of accusations; analysis of competitors' activity; analysis of the current state of development of a particular industry; monitoring the applications of patent trolls in order to invalidate such patents. The types of patent searches on various databases are outlined, 
namely on the subject of relevance of the invention and ways to solve the technical problem; novelty of the invention; the validity of the patent; nominal patent search; search for non-infringement of the rights of third parties. Particular attention is paid to the problem of high activity in Ukraine of patent trolls - persons who patent foreign or well-known developments in their name in order to further abuse the rights, which is a deterrent to innovation and economic development. The conclusion about the role of patent information to ensure further scientific, technical and economic progress is substantiated.

Keywords: patent information, patent searches, databases, types of patent searches, scientific and technological progress, economic development.

Постановка проблеми. У сучасних умовах господарювання як в Україні, так і в інших країнах світу, важливого значення набуває досягнення беззаперечних та стійких конкурентних переваг. Успіху досягають ті економічні агенти, діяльність яких ґрунтується на продукуванні та використанні інновацій, актуальних винаходів, що здатні забезпечити підґрунтя для сталого розвитку. Водночас генерування якісно нових ідей можливе завдяки вивченню поточних технологій, технічних рішень, які використовуються конкурентами. Відтак, постає необхідність виконання ґрунтовних патентних досліджень на предмет виявлення релевантної інорормації, що також дозволяє уникнути витрачання значних коштів і зусиль для розробок неактуальних та безперспективних технічних рішень.

Україна 3 іï численними економічними, політичними, науково-технічними проблемами повинна чітко усвідомлювати увесь могутній потенціал патентних досліджень та всіляко сприяти їхньому проведенню для стимулювання науково-технічного та економічного зростання. Відкритість баз даних, де міститься колосальний масив патентної інформації у розрізі країн, заявників, винахідників, патентних відомств $€$ потужним каталізатором активізації винахідницької діяльності та ефрективної комерціалізації ії̈ результатів. Отже, патентні пошуки є важливим інструмент забезпечення науково-технічного прогресу та економічного зростання, а тому $\epsilon$ беззаперечною доцільність його використання як бізнес-суб'єктами, так і науково-дослідницькими інституціями держави.

Аналіз останніх досліджень і публікацій. Як свідчать результати наших досліджень, питанням патентних пошуків, змісту та видам патентної інформації, їхнім можливостям в інфрормаційному забезпеченні зростання як на макро-, так і мікроекономічному рівнях приділено недостатньо уваги з боку науковців. Водночас можна виділити праці за окресленою тематикою таких науковців, як зокрема Артамонова Н.О., Філіпова Л.Я. [1], Косско Т.Г., Павлиго Т.М. [5], Филь Р.С., Филь С.П. [9].
Виділення невирішених раніше частин загальної проблеми. Малодослідженість даного питання привернуло нашу увагу, а відтак визначило напрями наукових пошуків за даною проблематикою.

Постановка завдання. Метою даної статті $€$ з'ясування ролі патентних пошуків як інструменту отримання патентної інфрормації для забезпечення науково-технічного та економічного розвитку.

Виклад основного матеріалу дослідження. Сучасна економіка $\epsilon$ результатом науково-технічної діяльності винахідників, раціоналізаторів, та пов'язана із інтелектуальним потенціалом інженерів. Тому для створення конкурентоздатного продукту розробники використовують патентну інфоормацію на всіх етапах життєвого циклу об'єктів науки та техніки. На основі ії використання ґрунтується подальша розробка технічних нововведень і ïх патентування, визначаються перспективи комерціалізації створених об'єктів промислової власності, вирішуються питання просування на ринку нових об'єктів техніки і забезпечується їхня патентна чистота та ін. [9, с. 150].

Патентна інформація включає технічну та юридичну інфрормацію, що міститься в патентних документах, які періодично публікуються патентними відомствами. Також вона охоплює інфрормацію як виданих патентів, так і заявок на патент. Своєю чергою, патентні документи включають не лише зміст опублікованих патентних документів, але й також бібліографрічну та іншу інфрормацію, що стосується патентів на винаходи, свідоцтв винахідників, патентів на корисні моделі.

Як зауважують Н.О. Артамонова, Л.Я. Філіпова, вітчизняні та іноземні фрахівці в останні роки активно досліджують інноваційний потенціал патентної інфрормації і його вплив на розвиток науки та трансфер результатів наукових досліджень. Патентні документи мають свої специфрічні властивості, що впливають на наукову комунікацію. Головною серед властивостей патентного документа $\epsilon$ його соціальна спрямованість, яка сприяє прогресу в науково-технічній сорері $[1$, с. 5]. 


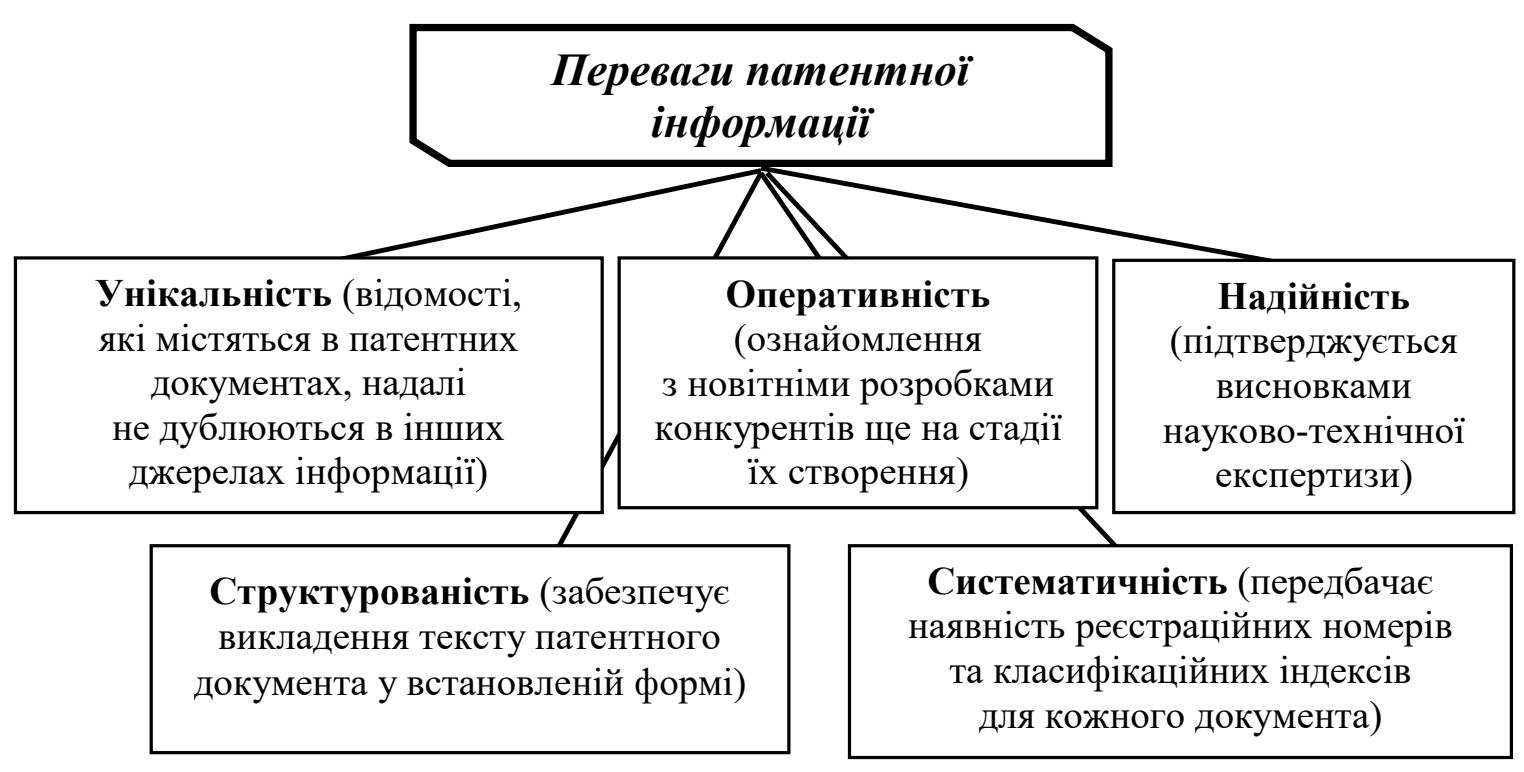

Рис. 1. Переваги патентної інформації

Джерело: складено автором за [9, с. 151]

Переваги патентної інфрормації представлені на рис. 1.

Ключові положення, алгоритм проведення патентних досліджень та форма звіту визначенні дСТУ 3575-97 «Патентні дослідження. Основні положення та порядок проведення» [3]. Під час проведення патентних досліджень використовують широке коло джерел патентної та іншої науково-технічної інорормації. Сучасні технології дозволяють ії̈ узагальнити та систематизувати у відповідних електронних базах даних (БД), що значно полегшує доступ до неї користувача.
В Україні відомчим органом, що безпосередньо реалізує патентну політику, $€$ ДП «Український інститут інтелектуальної власності» (Укрпатент). В Укрпатенті створені та фрункціонують декілька інтерактивних баз даних, які доступні через мережу Інтернет (рис. 2).

Отже, в Україні сорормовано потужну мережу баз даних, у яких містить значний масив накопиченої патентної інформації. Однак інтелектуальна власність - поняття не регіонального, а глобального значення, а тому особливо актуальними та затребуваними для

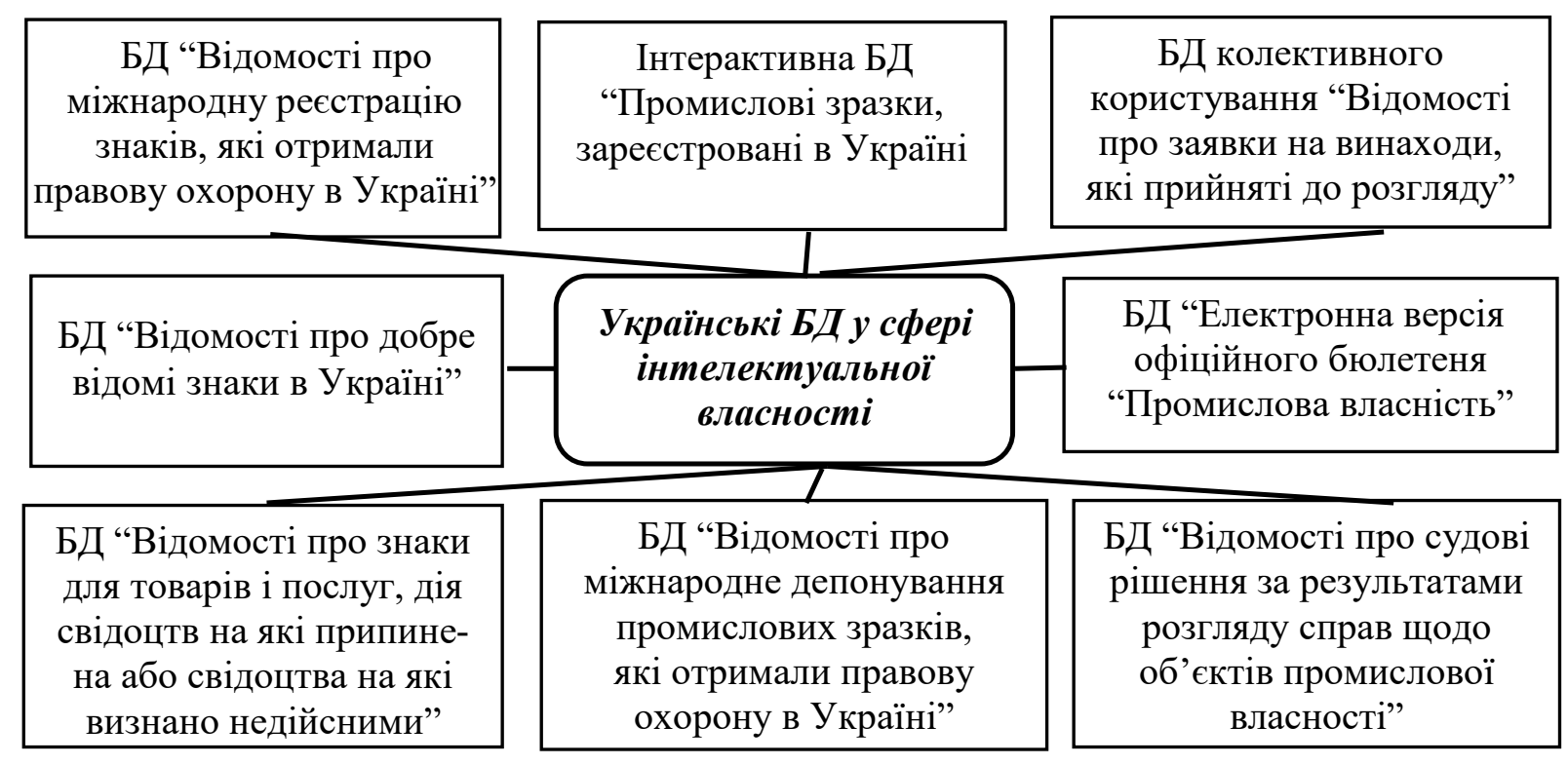

Рис. 2. Українські бази даних у сфері інтелектуальної власності Джерело: складено автором на основі [8] 


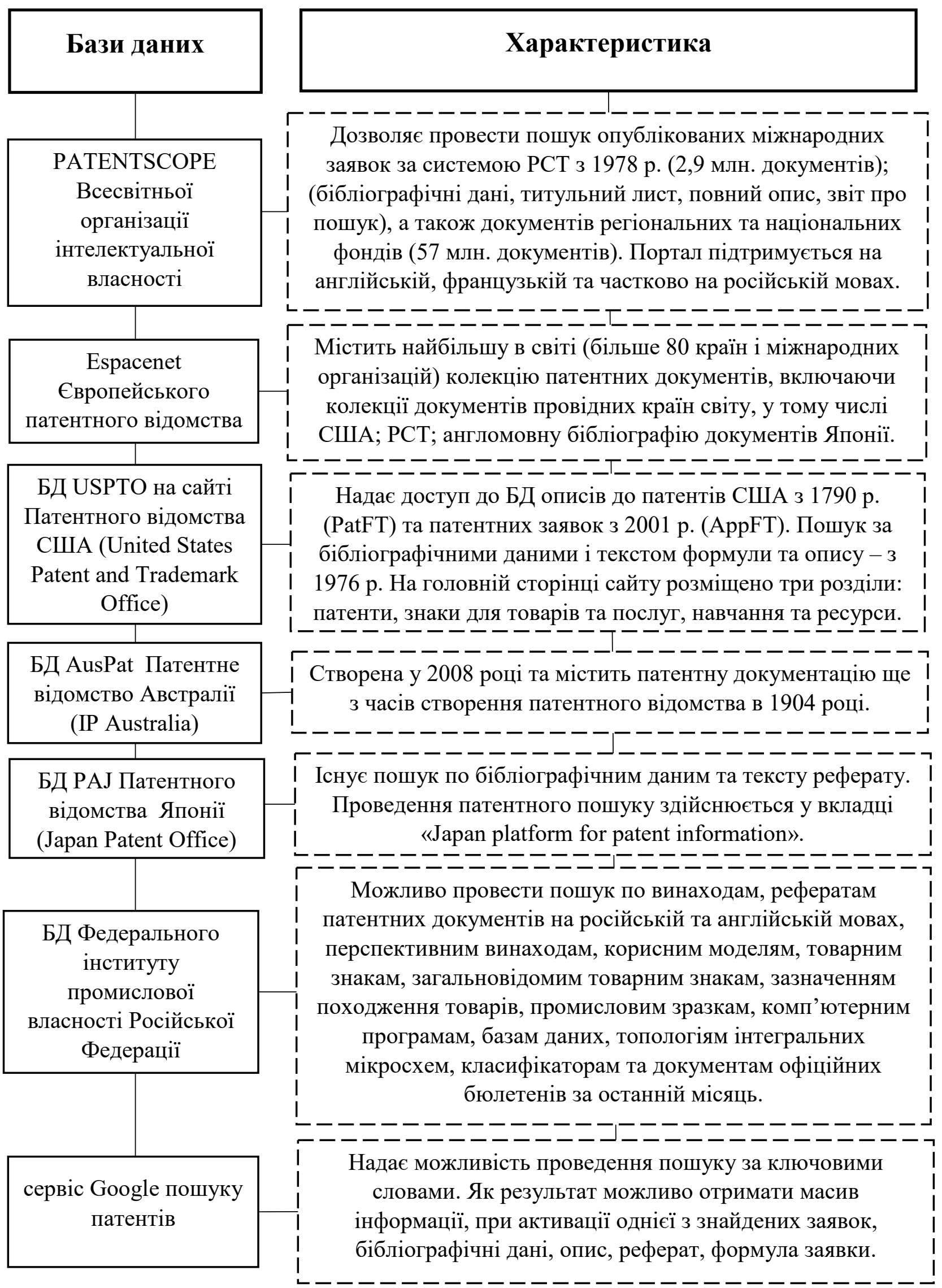

Рис. 3. Міжнародні бази даних у сфері інтелектуальної власності Джерело: складено автором на основі [2; 11-15] 
проведення патентних пошуків $€$ бази даних інших країн та міжнародних організацій. Їхній опис наведено на рис. 3.

Огляд баз даних і пошукових сервісів патентної інфрормації дозволяє зробити висновок, що світовою спільнотою напрацьовано ефективний механізм виконання патентних досліджень, що забезпечує ґрунтовність, всебічність, релевантність отриманих даних у розрізі країн, галузей винахідницької діяльності, окремих патентних відомств, заявників, винахідників тощо.

Патентний пошук $є$ важливим кроком при прийнятті рішення про патентування, а також інструментом аналізу ризиків звинувачення в порушенні прав, конкурентного аналізу та навіть моніторингу діяльності патентних тролів. Відкритість пошукових систем дозволяє забезпечити доступність патентної інформації для всіх зацікавлених осіб, однак дуже важливим моментом є вірна інтерпретація та розуміння й аналізування такої інформації.

В першу чергу, необхідно чітко сфрормулювати мету проведення патентних пошуків. Для прикладу, їх можна виконувати задля: оцінки можливості патентування розробленого технічного рішення; оцінки ризиків порушення прав третіх осіб та ймовірності звинувачень; аналізу діяльності конкурентів; аналізу поточного стану розвитку певної галузі; моніторингу заявок патентних тролів у цілях визнання таких патентів недійсними.

Відповідно до цілей патентних досліджень можна виділити наступні типи патентних пошуків за різними базами даних:

1. На предмет актуальності винаходу та шляхів вирішення технічної проблеми. Відповідно проводиться поточний пошук 3 метою перевірки рівня розвитку в певній технічній галузі; він спрямований на виявлення можливостей досягнення певного результату у вирішення виявленої технічної проблеми на основі дослідження патентних документів. Виконання таких пошуків дозволяє уникнути витрачання значних коштів та зусиль на вирішення проблем, які вже $€$ вирішеними, та направити їх у напрямі ще невирішених.

Також пошуки такого роду $є$ важливими при розгляді питання ліцензування або придбання певної технології. Результати досліджень становлення правової охорони певної розробки та поточний стан можуть становити суттєву користь при обговоренні умов ліцензійного договору.

2. Пошуки на предмет новизни винаходу, що $€$ важливим елементом його патентоз- датності. Такі пошуки націлені на отримання відповіді на запитання, чи можливо отримати патент на винахід.

3. Пошуки на предмет дійсності патенту. Цей тип пошуку стає затребуваним у зв'язку з активізацією в Україні діяльності патентних тролів - осіб, які патентують чужі або відомі розробки на своє ім'я 3 метою подальшого зловживання правами. У даному випадку завданням спеціаліста $€$ пошук всіх відомостей, які паплюжать новизну запатентованого об'єкта [6].

Як відзначає судовий експерт Науководослідного центру судової експертизи з питань інтелектуальної власності Ю. Охромєєв, саме поняття «патентний тролінг» виникло у США та позначало фрірми, які безпосередньо не займались виробництвом, а тільки скуповували патенти й ініціювали судові процеси, вимагаючи заборонити виробництво або сплату роялті, і в такий спосіб заробляли гроші. Фактично, патентні тролі в США не були ні виробниками, ні винахідниками, а тільки володіли майновими правами на об'єкти інтелектуальної власності та реалізовували ці права виключно через заборони. Власне, і тому отримали назву [7]. Як приклад можна навести ситуацію, коли один 3 відомих патентних тролів, компанія NTP Inc. «заробила» на патентній війні 3 компанією - виробником телефонів Blackberry більше 600 мільйонів доларів, а інший відомий патентний троль VirnetX, який отримав патент на технології сервісу відеозв'язку, внаслідок чого подав позов до найлояльнішого до патентних тролів суду - техаського суду, виграв 368 мільйонів доларів у компанії Apple. Також статистика судочинства між компаніями показує, що більше половини позовів у сфрері інтелектуальної власності подаються саме патентними тролями [4].

Своєю чергою, в Україні у поняття «патентний троль» вкладений абсолютно інший зміст, що пов'язано із особливостями вітчизняного законодавства про охорону інтелектуальної власності та отримання двох видів патентів під відповідальність заявника: патенту на корисну модель і патенту на промисловий зразок. При цьому для отримання такого патенту достатньо тільки правильно скласти заявку на отримання патенту та сплатити всі збори, передбачені законодавством. Відповідно до чинного законодавства видача таких патентів відбувається під відповідальність заявника. Тобто жодним чином не перевіряється на предмет новизни технічне рішення чи дизайн таких об'єктів інтелектуальної власності. Після отримання такого 
патенту його власник заволодіває повним пакетом юридичних інструментів для забезпечення захисту своїх прав інтелектуальної власності, як, наприклад, цивільно-правовий спосіб захисту, кримінально-правовий спосіб захисту чи захист прав інтелектуальної власності в адміністративному порядку, зокрема, захист на митному кордоні [7].

Як приклад патентного тролінгу в Україні можна навести ситуацію, коли на митному кордоні були заблоковані товари, які можна вважати загальновідомими (а саме гумові пробки для закупорювання фрлаконів, що широко використовувані у фрармакології), - справа № 760/20577/14-ц, ухвалу у якій винесено Вищим спеціалізованим судом України з розгляду цивільних і кримінальних справ від 22.06.2016, а також справа № 826/8074/16, ухвалу в якій винесено Київським апеляційним адміністративним судом від 05.07.2016, за якою запатентованими товарами були бордюри для квітників, постаменти для пам'ятників та інші типові вироби з граніту [10].

Варто відзначити, що патентний пошук 3 метою визнання патенту недійсним проводиться не лише 3 метою боротьби 3 патентними тролями, а й при звинуваченні в порушенні патентних прав, оскільки перш ніж знімати з виробництва продукт, запатентований конкурентами, доцільно все ж таки оцінити всі можливості, в тому числі й визнання патенту недійсним.

4. Іменний патентний пошук націлений на виявлення патентів, пов'язаних з тією чи іншою особою - як юридичною, так і фрізичною.

5. Пошук на предмет непорушення прав третіх осіб (т. зв. Freedom to Operate), який доцільно проводити при виході на новий ринок з певним продуктом або при виході з новим продуктом на існуючий ринок. На відміну від пошуку на патентоздатність, пошук Freedom to Operate проводиться у кожній країні зокрема, що пов'язано 3 тим, що патентна охорона обмежена територіальними межами, і в одній країні технологія може бути не запатентована, тоді як в іншій країні ії використання підпадає під дію патенту. На основі результатів такого пошуку можна прийняти рішення про доцільність і оцінку наслідків виходу компанії на нові ринки незалежно від того, чи планує компанія надалі патентувати дану розробку чи ні.

Висновки. Патентна інорормація $€$ надзвичайно важливим джерелом даних для забезпечення подальшого науково-технічного та економічного розвитку. Ї̈̈ можуть використовувати, як окремі винахідники, R\&D-центри компаній, підприємства, так і науково-дослідні інститути країн.

Світовою спільнотою напрацьовано ефективний механізм виконання патентних пошуків, що забезпечує ґрунтовність, всебічність, релевантність отриманих даних у розрізі країн, галузей винахідницької діяльності, окремих патентних відомств, заявників, винахідників тощо, що, своєю чергою, є важливим інструментом забезпечення подальшого науковотехнічного поступу та економічного зростання.

Результати патентних пошуків слугують основою для розроблення технічно й економічно обґрунтованої та раціональної $з$ юридичної точки зору стратегії розвитку бізнесу, а синергетичний ефект здатний забезпечити економічний та науково-технічний розвиток країни загалом. Розроблення бізнес-стратегій на основі результатів патентного пошуку $€$ подальшими перспективами наукових досліджень у даному напрямі.

\section{СПИСОК ВИКОРИСТАНИХ ДЖЕРЕЛ:}

1. Артамонова Н. О., Філіпова Л. Я. Патентна документація в системі інформаційного забезпечення науки: сутність, функції, значення. Бібліотекознавство. Документознавство. Інформологія. 2016. № 4. С. 4-10. URL: http://nbuv.gov.ua/UJRN/bdi_2016_4_3 (дата звернення: 16.02.2021).

2. БАЗЫ ДАННЫХ. Федеральный институт промышленной собственности. URL: https://www.fips.ru/ elektronnye-servisy/informatsionno-poiskovaya-sistema/bazy-dannykh.php (дата звернення: 21.04.2021).

3. ДСТУ 3575-97 «Патентні дослідження. Основні положення та порядок проведення», Держстандарт України. Київ, 1997. URL: https://nuph.edu.ua/wp-content/uploads/2015/02/ДСТУ-3575-97-Патентні дослідження-pdf (дата звернення: 24.04.2021).

4. Кидалов І. Патентні війни і патентний тролінг в Україні: юридичні аспекти. URL: https://kydalov-partners.com/uk (дата звернення: 20.03.2021).

5. Косско Т. Г., Павлиго Т. М. Патентні дослідження, їх актуальність на шляху інноваційного розвитку. Наука та інновації. 2014. Т. 10. № 1. С. 65-70. URL: http://scinn.org.ua/sites/default/files/pdf/2014/N1/Kossko.pdf (дата звернення: 21.03.2021).

6. Основи проведення патентного пошуку. URL: https://ipstyle.ua/ua/osnovi-provedennja-patentnogoposhuku/ (дата звернення: 05.03.2021). 
7. Охромєєв Ю. Патентний тролінг - ахіллесова п'ята системи охорони інтелектуальної власності в Україні. Юридична Газета online. 02 лютого 2015. № 5(451). URL: https://yur-gazeta.com/dumka-eksperta/patentniytroling--ahillesova-pyata-sistemi-ohoroni-intelektualnoyi-vlasnosti-v-ukrayini.html (дата звернення: 15.02.2021).

8. Патентна інфрормація вільного доступу. URL: http://ipr.nas.gov.ua/?page_id=302 (дата звернення: 18.02.2021).

9. Филь Р. С., Филь С. П. Патентна інформація як складова науково-технічної діяльності. Наука і правоохорона. 2014. № 2. C. 149-155. URL: http://nbuv.gov.ua/UJRN/Nip_2014_2_26 (дата звернення: 15.02.2021).

10.Що таке патентний тролінг? URL: https://taxlink.ua/ua/analytics/intelektualna-vlasnist/shcho-takepatentniy-troling/ (дата звернення: 17.04.2021).

11.AusPat. URL: http://pericles.ipaustralia.gov.au/ols/auspat/ (дата звернення: 15.02.2021).

12. ESPACENET. URL: https://worldwide.espacenet.com/patent/my-espacenet (дата звернення: 15.02.2021).

13. Japan platform for patent information. URL: https://www.j-platpat.inpit.go.jp/ (дата звернення: 16.02.2021).

14.PATENTSCOPE. Простой поиск. URL: https://patentscope.wipo.int/search/ru/search.jsf (дата звернення: 16.02.2021).

15. USPTO. Search for patents. URL: https://www.uspto.gov/patents/search (дата звернення: 16.02.2021).

\section{REFERENCES:}

1. Artamonova N. O., Filipova L. Ya. (2016) Patentna dokumentatsiia v systemi informatsiinoho zabezpechennia nauky: sutnist, funktsii, znachennia [Patent documentation in the system of information support of science: essence, functions, meaning]. Bibliotekoznavstvo. Dokumentoznavstvo. Informolohiia, no. 4, pp. 4-10. Available at: http://nbuv.gov.ua/UJRN/bdi_2016_4_3 (accessed 16 February 2021).

2. BAZY DANNYKH. Federalnyi instytut promyshlennoi sobstvennosty [DATABASES. Federal Institute of Industrial Property]. Available at: https://www.fips.ru/elektronnye-servisy/informatsionno-poiskovaya-sistema/bazydannykh.php (accessed 21 April 2021).

3. SSTU 3575-97 "Patentni doslidzhennia. Osnovni polozhennia ta poriadok provedennia" [Patent research. Basic provisions and procedure]. State Standard of Ukraine. Kyiv, 1997. Available at: https://nuph.edu.ua/wpcontent/uploads/2015/02/DSTU-3575-97-Patent research-pdf (accessed 24 April 2021).

4. Kydalov I. Patentni viiny i patentnyi trolinh $\vee$ Ukraini: yurydychni aspekty [Patent wars and patent trolling in Ukraine: legal aspects]. Available at: https://kydalov-partners.com/uk (accessed 20 March 2021).

5. Kossko T. G., Pavlyho T. M. (2014) Patentni doslidzhennia, yikh aktualnist na shliakhu innovatsiinoho rozvytku [Patent research, their relevance in the path of innovative development]. Nauka ta innovatsii, T. 10, no. 1, pp. 65-70. Available at: http://scinn.org.ua/sites/default/files/pdf/2014/N1/Kossko.pdf (accessed 21 March 2021).

6. Osnovy provedennia patentnoho poshuku [Basics of patent search]. Available at: https://ipstyle.ua/ua/ osnovi-provedennja-patentnogo-poshuku/ (accessed 05 March 2021).

7. Okhromieiev Yu. (2015) Patentnyi trolinh - akhillesova piata systemy okhorony intelektualnoi vlasnosti v Ukraini [Patent trolling - Achilles heel of the intellectual property protection system in Ukraine]. Yurydychna Hazeta online, 02 liutoho 2015, no. 5(451). Available at: https://yur-gazeta.com/dumka-eksperta/patentniy-troling--ahillesova-pyata-sistemi-ohoroni-intelektualnoyi-vlasnosti-v-ukrayini.html (accessed 15 March 2021).

8. Patentna informatsiia vilnoho dostupu [Patent information of free access]. Available at: http:/lipr.nas.gov.ua/ ?page_id=302 (accessed 18 February 2021).

9. Fyl R. S., Fyl S. P. (2014) Patentna informatsiia yak skladova naukovo-tekhnichnoi diialnosti [Patent information as a component of scientific and technical activities]. Nauka i pravookhorona, no. 2, pp. 149-155. Available at: http://nbuv.gov.ua/UJRN/Nip_2014_2_26 (accessed 15 February 2021).

10. Shcho take patentnyi trolinh? [What is patent trolling?]. Available at: https://taxlink.ua/ua/analytics/ intelektualna-vlasnist/shcho-take-patentniy-troling/ (accessed 17 April 2021).

11. AusPat. Available at: http://pericles.ipaustralia.gov.au/ols/auspat/ (accessed 15 February 2021).

12. ESPACENET. Available at: https://worldwide.espacenet.com/patent/my-espacenet (accessed 15 February 2021).

13. Japan platform for patent information. Available at: https://www.j.jplatpat.inpit.go.jp/ (accessed 16 February 2021).

14.PATENTSCOPE. Prostoi poysk [Simple search]. URL: https://patentscope.wipo.int/search/ru/search.jsf (accessed 16 February 2021).

15. USPTO. Search for patents. Available at: https://www.uspto.gov/patents/search (accessed 16 February 2021). 